\title{
Pengangkatan Hakamain alam Proses Perceraian \\ (Studi Kasus Di Pengadilan Agama Kotamobagu)
}

Oleh: Nirmala Hasan

\begin{abstract}
Abstrak
Proses pengangkatan hakamain adalah inisiatif pokok datangnya dari Majelis Hakim, yaitu dalam tahapan pemeriksaan perkara tersebut ( proses jawab menjawab) hakim sudah dapat menilai perkara tersebut, selajutnya setelah pembuktian kedudukan perkaratersebut semakin jelas dan disinilah hakim mengangkat hakam, yaitu memerintahkan kedua belah pihak untuk mendatangkan orang yang dapat dipercaya, kemudian diambil sumpah oleh Majelis Hakim dalam pelaksanaan tugas tersebut, kemudian dibacakan putusan sela, selanjutnya hakamain melaksanakan tugasnya, setelah melaksanakan tugasnya hakamain melaporkan hasilnya kepada Majelis Hakim, apakah hasil dapat didamaikan ataupun tidak harus didengar oleh Majelis Hakim sebagai bahan pertimbangan, jika berhasil didamaikan, maka perkara tersebut harus dinyatakan selesai karena damai dan harus dicabut, sebaliknya jika tidak berhasil, dilanjutka dengan pemeriksaan akhir, yaitu masing-masing mengajukan kesimpulan. Hal ini sesuai aturan normatif pengangkatan hakamain dalam pasal 76 ayat ( 1 ) dan ( 2 ) Undang-Undang Nomor 7 Tahun 1989 dan Alqur'an surah AnNisa ayat 35
\end{abstract}

\section{PENDAHULUAN}

\section{LATAR BELAKANG MASALAH}

Dinamika dan problema yang berlangsung dikalangan masyarakat, secara individual khususnya dalam nuansa ruang lingkup kekluargaan atau dalam istilah hukum disebut dengan ahwalu asyakhsiyah ${ }^{1}$ yaitu perdata-perdata khusus yag menyangkut tentang rumah tangga, khususnya yang berlangsung di negara

\footnotetext{
${ }^{1}$ Lihat, Abdul Karim Zaidan, Nizam, al-Qadha (Cet I; Baqdad, al-‘any, 1404/1984) $\quad$ h.54
} 
Indonesia, oleh pihak pemerintah melalui undang undang telah menetapkan suatu institusi yang mengaturnya, yaitu Peradilan Agama.

Eksistensi Peradilan Agama oleh Undang Undang Dasar 1945 secara implisit diatur dalam pasal 24 ayat 1 dan 2 Undang Undang Dasar 1945, sebagai berikut :

1) Kekuasaan kehakiman dilakukan oleh sebuah Mahkamah Agung dan lain lain Badan Kehakiman menurut undang-undang.

2) Susunan dan kekuasaan badan-badan kehakiman itu diatur dengan undangundang. ${ }^{2}$

\section{PROSES PERCERAIAN}

A. Kewenangan Absolut Pengadilan Agama

Kewenangan juga di kenal dengan istilah yuridiksi dalam istilah hukum yaitu kewenangan masing-masing Pengadilan. Kata ini berasal dari Bahasa Belanda "Jurisdictie" yang berarti : kekuasaan atau wewenang untuk mengadili. ${ }^{3}$

Dalam hukum acara perdata dikenal dua bentuk yuridiksi, atau sering juga disebut dengan kompetensi, yaitu kompetensi absolut dan kompetensi relatif. Yang dimaksud dengan kompetensi absolut adalah : kewenangan mengadili berdasarkan materi yang telah dibatasi atau diatur oleh undang-undang, sedangkan kompetensi relatif, adalah : kewenangan mengadili antara Pengadilan Agama berdasarkan wilayah hukum atau juga disebut dengan kompetensi nisbi. ${ }^{4}$

\footnotetext{
${ }^{2}$ Lihat Undang-Undang Dasar 1945, pasal 24 ayat 1 dan 2 Bab IX tentang kekuasaan kehakiman.

${ }^{3}$ J.C.T. Simorangkir, Kamus Hukum, ( Cet, II; Jakarta, Aksara Baru, 1980 ) h.83

${ }^{4}$ Lihat, H.A. Mukti Arto, praktek perkara perdata pada Pengadilan Agama( Cet. I; Yogyakarta, Pustaka Pelajar, 1996 ) h. 44, Lihat juga, Sudikno Mertokusumo, Hukum Acara Perdata Indonesia ( Edisi ke empat, Cet. I;Yogyakarta, 1993 ) h. 64
} 
Pengertian tersebut, memiliki relevansi dengan apa yang di jelaskan dalam nizam al-Qadha, pada bab lima tentang wilayah al-mazhalim awu qadha almazhalim. $^{5}$

Kompetensi relatif diatur secara umum dalam pasal 118HIR ( HET HRZIENCE INDONESIA REGLEMENT ) / 142 R.Bg ( Rechtsreglement Voor de Buitengewesten $)^{6}$ dan secara khusus diatur dalam berbagai peraturan peraturan perundang-undangan. Pada asasnya gugatan diajukan ke Pengadilan Agama ditempat tinggal Pemohon, kecuali undang-undang menentukan lain. Pada penjelasan pasal tersebut, Tresna mengemukakan bahwa segala orang dan badan hukum pada asasnya mempunyai kewenangan untuk melakukan perbuatan hukum. ${ }^{7}$

Pada bab III pasal 49 sampai dengan pasal 53 Undang-Undang Nomor : 7 Tahun 1989 dijelaskan tentang kewenangan dan kekuasaan mengadili yang menjadi beban tugas Peradilan Agama. Dalam pasal 49 ditentukan bahwa Pengadilan Agama bertugas dan berwenang memeriksa, memutuskan dan menyelesaikan perkaraperkara ditingkat pertama antara orang-orang yang beragama islam, serta wakaf dan shadaqah. ${ }^{8}$

Pada penjelasan pasal tersebut, menyatakan bahwa bidang perkawinan yang menjadi kewenangan dan kekuasaan Pengadilan Agama adalah hal-hal yang di atur dalam Undang-Undang Nomor : 1 Tahun 1974 Tentang Perkawinan, yaitu :

${ }^{5}$ Lihat, abdul Karim Zaidan, Nizham al-qadha ( Cet. I; Baqdad, al - a'any, 1984 / 1404.H ) h. 299

${ }^{6}$ Het Herzience Indonesia Reglement ( HIR ) atau Rechtsreglement Voor de Buitengewesten ( R.Bg ) adalah salah satu hukum acara yang berlaku di Pengadilan Agama, hukum acara yang lain adalah : Reglement op de Bugerlijke Rechtsvordering ( B.Rv ), Inlandsh Reglement ( IR ), Burgerlijke Wetbook Voor Indonesia ( BW ), Wetbook van Koophandel ( WvK ), lihat, H. Abdul Manan, penerapan Hukum Acara Perdata di Lingkungan Peradilan Agama ( Cet. I; Jakarta, Yayasan al- Hikmah, 2000 h. 6

${ }^{7}$ Lihat, R. Tresna, komentar HIR ( Cet. XI; Jakarta, Pradnya Paramita, 1984 ) h. 121

${ }^{8}$ Lihat, H, Zainal Abidin Abubakar ( penghimpun ), kumpulan peraturan perundang-undangan Dalam Lingkungan Peradilan Agama ( Cet. III; Jakarta, Yayasan al-hikmah, 1993 ) h. 259 
a. Izin beristri lebih dari seorang ;

b. Izin melangsungkan izin perkawinan bagi orang yang belum berusia 21 tahun, dalam hal orang tua atau wali keluarga dalam garis lurus ada perbedaan pendapat ;

c. Dispensasi kawin ;

d. Pencegahan perkawinan ;

e. Penolakan perkawinan;

f. Gugatan kelalaian atas kewajiban suami atau isteri ;

g. Perceraian karena talak ;

h. Gugatan perceraian ;

i. Penyelesaian harta bersama ;

j. Ibu dapat memikul biaya penghidupan anak bila bapak yang seharusnya bertanggung jawab tidak memenuhinya;

k. Penentuan kewajiban memberi biasay penghidupan oleh suami kepada bekas isteri atau penentuan suatu kewajiban bagi bekas isteri ;

1. Putusan tentang sah atau tidaknya seorang anak ;

m. Putusan tentang pencabutan kekuasaan orang tua;

n. Penunjukkan kekuasaan wali ;

o. Penunjukkan orang lain sebagai wali oleh Pengadilan Agama dalam hal kakuasaan seorang wali dicabut;

\section{B. Gugatan dan Permohonan Cerai}

Pasal 73 ayat ( 1 ) Undang-Undang Nomor : 7 Tahun 1989 menyebutkan sebagai berikut : Gugatan perceraian diajukan oleh isteri atau kuasanya kepada pengadilan yang daerah hukumnya meliputi tempat kediaman Penggugat, kecuali apabila Penggugat dengan sengaja meninggalkan tempat kediaman bersama tanpa izin Tergugat. ${ }^{9}$

${ }^{9}$ H. Zainal Abidin Abubakar, op., cit., h. 264 
Pasal ini secara permanen menetapkan bahwa dalam perkara cerai gugat yang bertindak dan berkedudukan sebagai penggugat adalah isteri dan suami ditempatkan sebagai pihak tergugat.Dengan demikian masing-masing suami telah mempunyai jalur tertentu dalam upaya menentukan perceraian.

Cerai gugat jika dihubungkan dengan hukum acara, adalah bersifat murni sebagai contantius yaitu ada sengketa perkawinan yang menyangkut perkara perceraian. ${ }^{10}$ Ada pihak-pihak yang sama-sama berdiri sebagai pihak tergugat. Oleh karena sifat gugatan bersifat contantiuss, serta pihak-pihak terdiri dari dua subjek yang saling berhadapan dalam kedudukan hukum yang sama derajat, proses pemeriksaan cerai gugat benar-benar murni bersifat contantius.

Dalam gugatan cerai ini, maka isteri atau penggugat mengajukan kepada Pengadilan Agama didaerah hukumnya meliputi tempat kediamannya.

\section{Akibat dan Alasan-Alasan Perceraian.}

Akibat perceraian dijelaskan pada Instruksi Presiden Nomor : 1 Tahun 1991 tentang Kompilasi Hukum Islam ( KHI ) pasal 149 sampai dengan pasal 152 dan pasal 156 serta pasal 162 secara rinci penulis ungkapkan sebagai berikut :

Pasal 149: Bilamana perkawinan putus karena talak, maka bekas suami wajib :

a. Memberikan Mut'ah yang layak kepada bekas isterinya, baik berupa uang atau benda, kecuali bekas isteri, tersebut qobla al dukhul.

b. Memberikan nafkah, maskan, kiswah kepada bekas isteri selama masa iddah, kecuali bekas isteri telah dijatuhi talak bain atau nusyuz dan dalam keadaan tidak hamil.

\footnotetext{
${ }^{10}$ Lihat, M. Yahya Harahap, Kedudukan Kewenangan dan Acara Peradilan Agama Undang-Undang
} Nomor : 7 tahun 1989 ( Cet. I; Jakarta, Kartini, 1990 ) h. 252 
c. Melunasi mahar yang masih terhutang seluruhnya, dan separuh apabila qobla al dukhul.

d. Memberikan biaya hadhanah untuk anak-anaknya yang belum mencapai umur 21 tahun.

Pasal 150: Bekas suami berhak melakukan rujuk kepada bekas isterinya yang masih dalam iddah.

Pasal 151: Bekas isteri selama dalam iddah, wajib menjaga dirinya, tidak menerima pinangan dan tidak menikah dengan pria lain.

Pasal 152: Bekas isteri berhak mendapat nafkah iddah dari bekas suaminya kecuali bila ia nusyuz. ${ }^{11}$

Pasal 156: Akibat putusnya perkawinan karena perceraian ialah :

a. Anak yang belum mumayyiz berhak mendapat hadhanah dari ibunya, kecuali bila ibunya telah meninggal dunia, maka kedudukannya di gantikan oleh :

1. Wanita-wanita dalam garis lurus dari ibu;

2. Ayah;

3. Wanita-waita dalam garis lurus keatas dari ayah;

4. Saudara perempuan dari anak yang bersangkutan;

5. Wanita-wanita kerabat sedarah menurut garis samping dari ayah;

6. Wanita-wanita kerabat sedarah menurut garis samping dari ayah;

b. Anak yang sudah mumayyiz berhak memilih untuk mendapatkan hadhanah dari ayah atau ibunya.

\footnotetext{
${ }^{11}$ H. Zainal Abidin Abubakar, op., cit., h. 341
} 
c. Apabila pemegang hadhanah ternyata tidak dapat menjamin keselamatan jasmani dan rohani anak, meskipun biaya nafkah dan hadhanah telah dicukupi, maka atas permintaan kerabat yang bersangkutan Pengadilan Agama dapat memindahkan hak hadhanah kepada kerabat lain yang mempunyai hak hadhanah pula.

d. Semua biaya hadhanah dan nafkah anak menjadi tanggungan ayah menurut kemampuannya,sekurang-kurangnya sampai anak tersebut dewasa dan dapat mengurus sendiri ( 21 tahun ).

e. Bilamana terjadi perselisihan mengenai hadhanah dan nafkah anak, Pengadilan agama memberikan putusannya berdasarkan ( a ), ( b ), ( c ), dan ( d ).

f. Pengadilan dapat pula dengan mengingat kemampuan ayahnya menetapkan jumlah biaya untuk memelihara dan pendidikan anakanak yang tidak turut padanya. ${ }^{12}$

Pasal 162 : Bilamana li'an terjadi maka perkawinan itu putus untuk selamanya dan anak yang dikandung dinasibkan kepada ibunya, sedang suami terbebas dari kewajiban memberi nafkah. ${ }^{13}$

Alas an-alasan perceraian yang termuat dalam Peratutan Pemerintah Nomor : 9 Tahun 1975, pasal 19, sebagai berikut :

Perceraian dapat terjadi karena alas an atau alas an-alasan :

a. Salah satu pihak berbuat zina atau menjadi pemabok, pemadat, penjudi, dan lain sebagainya yang sukar disembuhkan;

${ }^{12}$ Ibid., h. 343

${ }^{13}$ Ibid., h. 343 
b. Salah satu pihak meninggalkan pihak lain selama 2 ( dua ) tahun berturut-turut tanpa izin pihak lain dan tanpa alas an yang sah atau karena hal lain di luar kemampuannya;

c. Salah satu pihak mendapat hukuman penjara 5 ( lima ) tahun atau hukuman yang lebih berat setelah perkawinan berlangsung;

d. Salah satu pihak melakukan kekejaman atau penganiayaan berat yang membahayakan pihak yang lain.

e. Salah satu pihak mendapat cacat badan atau penyakit dengan akibat tidak dapat menjalankan kewajibannya sebagai suami/isteri.

f. Antara suami isteri terus menerus terjadi perselisihan dan pertengkaran dan tidak ada harapan akan hidup rukun lagi dalam rumah tangga. ${ }^{14}$

Alas an tersebut oleh Majelis Hakim akan diperiksa sesuai dengan alat-alat bukti yag akan diajukan oleh para pihak. Sehingga tidak semua alas an yang terdapat pada pasal tersebut harus sama prosesnya, seperti pada alas an karena dihukum lima tahun penjara. Alas an ini hanya cukup dibuktikan dengan salinan putusan yang telah mempunyai kekuatan hukum tetap dari Pengadilan Negeri bahwa suami ataupun isteri telah dipidana selama lima tahun. Cukup sederhana penerapannya tidak memerlukan penafsiran.

Dalam alas an salah satu pihak mendapat cacat sehingga tidak dapat melaksanakan kewajibannya. Hakim dapat memerintahkan pemeriksaan ke dokter ahli.Perintah hakim ini tidak langsung atas permintaan para pihak, tetapi karena keperluan hakim dan atas dasar ex officio atau berdasarkan jabatannya, hal ini tidak dapat mengurangi hak penggugat atau tergugat untuk meminta dilakukan pemeriksaan.Apabila ada permintaan sebaiknya hakim memerintahkan Tergugat untuk memeriksa kepada dokter yang telah ditentukan oleh hakim. ${ }^{15}$

${ }^{14}$ Ibid., h. 156

${ }^{15}$ Ibid., h. 15 


\section{PENGANGKATAN HAKAMAIN}

\section{A. Proses Pengangkatan Hakamain.}

Hakim disebut juga dengan juru damai ${ }^{16}$, hanya dapat dilaksanakan khusus dalam perkara perceraian, yang lebih khusus lagi perceraian tersebut dengan alas an syiqaq atau perpecahan ${ }^{17}$, sebagaimana tersebut pada pasal 76 ayat ( 2 ) Undangundang Nomor : 7 Tahun 1989, sebagai berikut :

"Pengadilan setelah mendengar keterangan saksi tentang sifat persengketaan antara suami isteri dapat mengangkat seorang atau lebih dari keluarga masing-masing pihak ataupun orang lain untuk menjadi hakam". ${ }^{18}$

Berpedoman pada pemeriksaan tahap pembuktian saksi yang diajukan para pihak sudah selesai diperiksa.Dari hasil pemeriksaan dalam pembuktian tersebut, majelis hakim telah mendapat gambaran tentang sifat persengketaan yang terjadi diantara suami isteri.

Jika majelis hakim berpendapat bahwa ada indikasi perkara tersebut bisa rukun kembali, maka majelis hakim mengangkat hakam ${ }^{19}$, dengan demikian inisiatif untuk mengangkat hakam adalah pihak majelis hakim berdasarkan analisis perkara yang bersangkutan.

Aturan normatif dalam pengangkatan hakamain merujuk kepada pasal 76 Undang-Undang nomor : 7 Tahun 1989 sebagaimana telah disebutkan diatas.

\footnotetext{
${ }^{16}$ Lihat, Ibnu Rusyd, Bidayatul Mujtahid, diterjemahkan oleh M.A. Abdurrahman dengan judul Bidayatul Mujtahid ( Cet. I; Semarang, Asy-Syifa', 1990 ) h. 554

${ }^{17}$ Ahmad Warson Munawwir, al-Munawwir Kamus Arab-Indonesia ( Yogyakarta, Unit Pengadaan Buku-Buku Ilmiah Keagamaan Pondok Pesantren al-Munawir 1984 ) h. 785

${ }^{18} \mathrm{H}$, Zainal Abidin Abu bakar ( penghimpun ) Kumpulan Peraturan Perundang-Undangan Dalam Lingkungan Peradilan Agama ( Cet. III; Jakarta, Yayasan al-Hikmah, 1993 ) h. 74

${ }^{19}$ Tomi Asram, Hakim pada Pengadilan Agama Kotamubagu, Wawancara, 6 juli 2004
} 
Inisiatif majelis hakim tersebut tidak menutup kemungkinan para pihak mengusulkan kepada majelis hakim untuk mengangkat hakam.Jika ini terjadi maka majelis hakim wajib menerima usul tersebut. Para pihak berhak mengusulkan siapa yang mereka usulkan untuk diangkat menjadi hakam, akan tetapi usulan meraka itu tidak mengikat hakim. Oleh karena penunjukan hakam yang disampaikan para pihak tidak mutlak mengikat, sebaiknya hakim menganjurkan kepada para pihak untuk mengusulkan beberapa orang serta dalam pengusulan tersebut itu dilengkapi dengan biodata masing-masing calon. Dari keterangan biodata itulah hakim meneliti satu persatu siapa yang paling tepat diangkat untuk menjadi hakam sesuai dengan pesyaratan yang ditentukan hukum islam, yakni cakap, jujur,memiliki kapasitas sebagai juru damai, berwibawa dan disegani oleh pihak suami isteri. Ada baiknya hakim menyuruh dan bertemu muka dengan orang-orang yang diusulkan para pihak yang memang tepat diagkat menjadi hakam, sekiranya hakim berpendapat orangorang yang diusulkan para pihak kurang tepat, hakim dapat mengangkat orang lain. Namun sebaiknya hakim menanyakan pendapat para pihak.Karena adalah tepat apabila hakam yang hendak diangkat mendapat persetujuan dari para pihak dalam melaksanakan pendekatan penyelesaian perselisihan.

Dari hasil observasi bahwa pada tahun 2004 perkara yang diterima oleh Pengadilan Agama Kotamubagu beluma ada yang diangkat hakamain, namun pada tahun 2002 satu perkara yang melalui proses hakamain yaitu perkara Nomor : 292/Pdt.G/2002/PA.Ktg dari jumlah perkara sebanyak 315 perkara, berikut ini tabel perkara pada tahun 2002 : 
TABEL VII

KEADAAN PERKARA PADA TAHUN 2002

\begin{tabular}{|l|l|l|}
\hline NO & JENIS PERKARA & JUMLAH \\
\hline 1 & Gugatan Cerai & 202 \\
2 & Permohonan Cerai & 98 \\
3 & Pencegahan Perkawinan & 3 \\
4 & Penolakan Perkawinan oleh PPN & 1 \\
5 & Harta Bersama & 3 \\
6 & Isbath Nikah & 1 \\
7 & Dispensasi Perkawinan & 1 \\
8 & Wali Adhal & 6 \\
\hline & Jumlah & 315 \\
\hline
\end{tabular}

Sumber Data : Data Registrasi Perkara Tahun 2004

Melihat volume tersebut dibandingkan dengan satu perkara yang dilakuakan hakamain persentasenya sangatlah minim, dengan menggunakan rumus : 1 / $300 \mathrm{x}$ $100=0,3 \%$

Sebagaimana telah disebutkan diatas bahwa pengangkatan hakamain harus dengan putus sela,maka menurut penulis perlu kiranya dituangkan pertimbangan majelis hakim dalam putusan sela Nomor : 292 / Pdt.G / 2002 / PA. Ktg, yaitu khusus tentang pertimbangan hukumnya sebagai berikut :

“ Menimbang bahwa pada tahap pembuktian ternyata kasus rumah tangga Penggugat dan Tergugatadalah syiqqaq dan Tergugat bertetap untuk merukunkan rumah tangganya, maka sesuai petunjuk Alqur' an ayat 35 Surah An-Nisa ayat 35dan pasal 76 ayat ( 1 ) dan ( 2 ) Undang-Undang Nomor : 7 tahun 1989, maka perlu untuk diangkat hakamain. 
Menimbang bahwa kewenangan dan tugas hakam dalam perkara syiqaq antara lain adalah hakam sama sekali tidak mempunyai wewenang menceraikan Penggugat dan Tergugat, akan tetapi bebas untuk bertindak dalam rangka mengadakan upaya perdamaian. “20

\section{B. Tugas Pokok Hakamain}

Sebagaimana penulis uraian diatas, bahwa musyawarah itu sangat mulia dan mempunyai dampak positif bagi kedua belah pihak, oleh karena pentingnya, maka Mahkamah Agung RI membuat Peraturan Mahkamah Agung tentang Mediasi ( sebagaimana telah diuraikan diatas ). Nilai kesamaan antara hakam dan mediator adalah sama-sama ingin mencapai tujuan perdamaian melalui musyawarah.

Oleh karena itu tugas hakam sungguh sangat mulia, melalui Alqur'an surah An-Nisa ayat 35 menyebutkan yang artiya : "Dan jika kamu khawatirkan ada persengketaan antara keduanya, maka kirimlah seorang juru damai dari keluarga lakilaki dan seorang juru damai dari keluarga perempuan. Jika kedua orang juru damai itu bermaksud mengadakan perbaikan, niscaya Allah memberi taufik kepada suami-isteri itu.Sesungguhnya Allah mengetahui lagi Maha Mengenal. “21

Makna ayat ini setidaknya memiliki tig unsur ${ }^{22}$ yaitu :

1. Salah satu dari suami isteri dapat mngambil hakam meskipun bukan keluarga yang dekat;

2. Jumhur ulama berpendapat bahwa fungsi hakam adalah memerintahkan suami isteri untuk berdamai;

3. Dapat juga mengutus satu orang dari pihak isteri maupun suami untuk menyelesaikan sengketa rumah tangganya.

\footnotetext{
${ }^{20}$ Pengadilan Agama Kotamobagu, Putusan Nomor : 292 / Pdt.G / 2002 / PA. Ktg

${ }^{21}$ Ibid., h. 123

${ }^{22}$ Abi Abdullah Muhammad ibn Ahmad Anshari al-Qurthubi, al-J ami'al-Q ur' an ( Bairut, Daar Ihya at-Turats al-Araby, 1405 H / 1985 M ) h. 178
} 
Tampak bahwa Undang-Undang Nomor : 7 Tahun 1989 pengangkatan hakam adalah bersifat fakultatif atau disebut sunnah, hal ini dapat dipahami melalui pasal 76 ayat ( 2 ) dalam kalimat "dapat mengangkat hakam", dengan demikian pengangkatan hakam adalah tindakan kasuistik, tergantung pada pendapat dan penilaian hakim.

\section{Dapat Pengangkatan Hakamain}

Maksud dan tujuan undang-undang dalam menentukan hakam, adalah sematamata untuk memperbaiki rumah tangga yang rusak sehingga mereka bisa islah kembali dan mempertahankan rumah tangganya hingga umur hidupnya. Disamping itu juga dari sisi penerimaan perkara, maka pihak Pengadilan akan senang jika ada perkara yang bisa damai, bahkan Mahkamah Agung tidak akan banyak menungak perkara.

Dari aspek non yustisial dampak pengangkatan hakam ini sangat mempengaruhi pysicologis yang bersangkutan dan juga terhadap keluarganya, demikian halnya dengan perkembangan anak-anak mereka, dengan kata lain bahwa sangat mempengaruhi terhadap pendidikan internal kekeluargaan.

Sebab kewajiban mendidik anak dirumah dapat dilaksanakan dengan mudah karena Tuhan telah menciptakan landasannya, yaitu adanya rasa cinta orang tua terhadap anaknya yang merupakan salah satu dari fitrahnya. Rasa cinta terlihat misalnya dalam Alqur'an surah al-Kahfi ayat 46, sebagai berikut :yang artinya : "Harta dan anak-anak adalah perhiasan kehidupan dunia tetapi amalan-amalan yang kekal lagi saleh adalah lebih baik pahalanya di sisi Tuhanmu serta lebih baik untuk menjadi harapan." ${ }^{23}$

\section{PENUTUP}

Kesimpulan

${ }^{23}$ Departemen Agama RI, op., cit., h. 450 
Berdasarkan apa telah diuraikan penulis pada bab-bab sebelumnya, maka dapatlah ditarik kesimpulan sebagai berikut :

1. Proses pengangkatan hakamain adalah inisiatif pokok datangnya dari Majelis Hakim, yaitu dalam tahapan pemeriksaan perkara tersebut ( proses jawab menjawab ) hakim sudah dapat menilai perkara tersebut, selajutnya setelah pembuktian kedudukan perkaratersebut semakin jelas dan disinilah hakim mengangkat hakam, yaitu memerintahkan kedua belah pihak untuk mendatangkan orang yang dapat dipercaya, kemudian diambil sumpah oleh Majelis Hakim dalam pelaksanaan tugas tersebut, kemudian dibacakan putusan sela, selanjutnya hakamain melaksanakan tugasnya, setelah melaksanakan tugasnya hakamain melaporkan hasilnya kepada Majelis Hakim, apakah hasil dapat didamaikan ataupun tidak harus didengar oleh Majelis Hakim sebagai bahan pertimbangan, jika berhasil didamaikan, maka perkara tersebut harus dinyatakan selesai karena damai dan harus dicabut, sebaliknya jika tidak berhasil, dilanjutka dengan pemeriksaan akhir, yaitu masing-masing mengajukan kesimpulan. Hal ini sesuai aturan normatif pengangkatan hakamain dalam pasal 76 ayat ( 1 ) dan ( 2 ) Undang-Undang Nomor 7 Tahun 1989 dan Alqur'an surah An-Nisa ayat 35.

2. Tugas pokok hakamain adalah berusaha optimal mungkin untuk memahami bentuk syiqaq antara suaimi isteri, kemudian hakamain berusaha seoptimal untuk mencari jalan dengan cara apapun juga untuk menuju kepada perdamaian atau islah.

3. Hakamain sangat berpengaruh terhadap perkara yang diadili, karena jika terjadi perdamaian atau islah, maka suami isteri akan lebih menekuni perjalanan rumah tangga serta anak-anak semakin terjamin kehidupan pysicologisnya, akan tetapi sebaliknya jika tidak berhasil, namun demikian harapan untuk mendapat hidayah sesuai petunjuk Alqur'an tersebut diatas, 
minimal akan dapat memupuk hubungan kekeluargaan yaitu pernah bersuaami isteri dan anak-anak sebagai alat penghubung. 


\section{DAFTAR PUSTAKA}

Abdul Karim Zaidan, Nizam, al-Qadha (Cet I; Baqdad, al-'any, 1404/1984)

Abdul Karim Zaidan, Nizham al-qadha ( Cet. I; Baqdad, al - a'any, 1984 / 1404.H )

Abi Abdullah Muhammad ibn Ahmad Anshari al-Qurthubi, al-Jami'al-Qur'an ( Bairut, Daar Ihya at-Turats al-Araby, 1405 H / 1985 M )

Ahmad Warson Munawwir, al-Munawwir Kamus Arab-Indonesia ( Yogyakarta, Unit Pengadaan Buku-Buku Ilmiah Keagamaan Pondok Pesantren al-Munawir 1984 )

H, Zainal Abidin Abu bakar ( penghimpun ) Kumpulan Peraturan PerundangUndangan Dalam Lingkungan Peradilan Agama ( Cet. III; Jakarta, Yayasan al-Hikmah, 1993)

H, Zainal Abidin Abubakar ( penghimpun ), kumpulan peraturan perundangundangan Dalam Lingkungan Peradilan Agama ( Cet. III; Jakarta, Yayasan al-hikmah, 1993 ).

H.A. Mukti Arto, praktek perkara perdata pada Pengadilan Agama( Cet. I; Yogyakarta, Pustaka Pelajar, 1996 ) h. 44, Lihat juga, Sudikno Mertokusumo, Hukum Acara Perdata Indonesia ( Edisi ke empat, Cet. I;Yogyakarta, 1993 )

H. Abdul Manan, penerapan Hukum Acara Perdata di Lingkungan Peradilan Agama ( Cet. I; Jakarta, Yayasan al- Hikmah, 2000

Ibnu Rusyd, Bidayatul Mujtahid, diterjemahkan oleh M.A. Abdurrahman dengan judul Bidayatul Mujtahid ( Cet. I; Semarang, Asy-Syifa', 1990 )

J.C.T. Simorangkir, Kamus Hukum, ( Cet, II; Jakarta, Aksara Baru, 1980 ) h.83

Lihat, R. Tresna, komentar HIR ( Cet. XI; Jakarta, Pradnya Paramita, 1984)

M. Yahya Harahap, Kedudukan Kewenangan dan Acara Peradilan Agama UndangUndang Nomor : 7 tahun 1989 ( Cet. I; Jakarta, Kartini, 1990 ) 
Pengadilan Agama Kotamobagu, Putusan Nomor : 292 / Pdt.G / 2002 / PA. Ktg

Undang-Undang Dasar 1945, pasal 24 ayat 1 dan 2 Bab IX tentang kekuasaan kehakiman. 